\title{
Penerapan Model Discovery Learning berbantuan Video dalam Pembelajaran IPS guna meningkatkan HOTS Siswa Kelas VIIA SMPN 3 Sambit
}

\author{
Mulin $\bowtie$, Universitas PGRI Madiun \\ Sudarmiani, Universitas PGRI Madiun \\ Muhammad Rifai, Universitas PGRI Madiun \\ mulin200369@gmail.com
}

\begin{abstract}
Abstrak: Penelitian ini bertujuan untuk meningkatkan HOTS siswa melalui penerapan model Discovery Learning berbantuan Video. Subyek penelitain adalah siswa kelas VIIA SMPN 3 Sambit, berjumlah 26 siswa. Penelitian ini menggunakan metode penelitian tindakan model Kemmis dan Mc. Taggart yang terdiri dari empat fase: perencanaan, tindakan, observasi, dan refleksi. Penelitian tindakan dilakukan dalam dua siklus dan masing-masing siklus terdiri dari 2 pertemuan. Data dikumpulkan melalui observasi, tes, dan dokumen. Teknik analisis data dalam penelitian ini adalah analisis data kualitatif dan kuantitatif. Hasil penelitian menunjukkan peningkatan HOTS secara signifikan. Tingkat pencapaian pada pra-siklus adalah 52,85\%, pada siklus I meningkat menjadi $63,31 \%$, dan pada siklus II menjadi $79,46 \%$. Penelitian ini membuktikan bahwa model discovery learning berbantuan Video merupakan salah satu model pembelajaran yang dapat meningkatkan HOTS siswa.
\end{abstract}

Kata kunci: Model Discovery Learning, Media Video, HOTS.

\begin{abstract}
This study aims to increase students' HOTS through the application of the Video-assisted Discovery Learning model. The research subjects were students of class VIIA SMPN 3 Sambit, totaling 26 students. This study uses the Kemmis and Mc model of action research. Taggart consists of four phases: planning, action, observation, and reflection. Action research was conducted in two cycles and each cycle consisted of 2 meetings. Data were collected through observation, tests, and documents. The data analysis technique in this research is qualitative and quantitative data analysis. The results showed a significant increase in HOTS. The level of achievement in the pre-cycle was $52.85 \%$, in the first cycle it increased to $63.31 \%$, and in the second cycle it became $79.46 \%$. This study proves that the video-assisted discovery learning model is one of the learning models that can increase students' HOTS.
\end{abstract}

Keywords: Model Discovery Learning, Media Video, HOTS.

Citation: Mulin, M., Sudarmiani, S., \& Rifai, M. (2022). Penerapan Model Discovery Learning berbantuan Video dalam Pembelajaran IPS guna meningkatkan HOTS Siswa Kelas VIIA SMPN 3 Sambit. Wewarah: Jurnal Pendidikan Multidisipliner, 1(1), 67 - 79.

\section{$(\mathrm{cc}) \mathrm{Br}_{\mathrm{B}}$}

Published by Program Pascasarjana Universitas PGRI Madiun. This work is licensed under the Creative Commons Attribution-NonCommercialShareAlike 4.0 International License. 


\section{PENDAHULUAN}

Dalam rangka mewujudkan tujuan Nasional, maka peningkatan kualitas proses dan hasil pembelajaran di setiap jenjang dan tingkat pendidikan perlu diwujudkan agar diperoleh kualitas sumber daya manusia Indonesia yang dapat menunjang Pembangunan Nasional. Tugas tersebut menjadi tanggung jawab semua tenaga pendidikan atau pihak-pihak yang terlibat dalam pengelolaan pendidikan. Pada posisi ini peran guru sangat menentukan, sebab gurulah yang terlibat langsung dalam pembelajaran disekolah. Seiring dengan adanya perubahan dalam paradigma pendidikan, yang sebelumnya menjadikan guru sebagai pusat (teacher centre) dalam pembelajaran dikelas, sekarang harus menjadikan siswa sebagai pusat (student centre) dengan melibatkan mereka (peserta didik) secara aktif dan selalu membawa mereka pada kondisi nyata di lingkungan sekitar. Peserta didik harus belajar memahami permasalahan-permasalahan yang ada di sekitarnya, sehingga menuntunnya untuk berbuat bagaimana bisa mencari jalan keluar guna menyelesaikan masalah nyata dalam kehidupan sehari-hari.

Pembelajaran abad 21 merupakan suatu pembelajaran yang bercirikan learning skill, skill, dan literasi. Learning skill yaitu kegiatan pembelajaran yang di dalamnya ditandai dengan adanya kerja sama, komunikasi, serta berpikir kritis dan kreatif. Keterampilan berpikir tingkat tinggi perlu dimiliki oleh semua peserta didik agar mereka dapat menyelesaikan permasalahan dalam kehidupan sehari-hari. Untuk dapat mengambil keputusan, peserta didik harus bisa berpikir kritis, sedangkan untuk dapat berpikir kritis peserta didik harus logis, reflekstif dan memiliki pengetahuan awal terkait dengan masalah yang dihadapi (Sani, 2019: 1)

Pada kenyataannya pembelajaran di sekolah cenderung masih diimplementasikan melalui model konvensional. Sebagaimana di kemukakan oleh Basuki, Sudarmiani, Rifai (2020: 61) Pembelajaran di kelas masih didominasi oleh guru hal tersebut berdampak mengurangi ruang gerak siswa untuk mengembangkan pola pikirnya. Pembelajaran model ini biasanya berlangsung dalam bentuk alih pengetahuan (transfer of knowledge) dari guru kepada peserta didik. Model konvensional juga dianggap sebagai penyebab rendahnya kualitas Pendidikan di Indonesia. Hal ini berarti bahwa peserta didik Indonesia baru memiliki kemampuan berpikir pada level LOTS (Lower Order Thinking Skills), dan belum memiliki kemampuan berpikir pada level HOTS (Higher Order Thinking Skills) sebagaimana sesuai dengan konsep pembelajaran abad 21, yaitu mencerminkan empat hal, yaitu berpikir kritis dan pemecahan masalah,kreativitas dan inovasi, komunikasi, dan kolaborasi (Sudarmiani, 2018: 160)

Permasalahan yang muncul ketika melakukan observasi di kelas VIIA SMPN 3 Sambit, diperoleh data bahwa guru di kelas tersebut telah menerapkan soal HOTS pada pembelajaran IPS. Namun masih terdapat banyak siswa yang kesulitan mengerjakan soal HOTS tersebut. Kemampuan siswa dalam mengerjakan soal HOTS IPS kelas VIIA, berdasarkan rata-rata total ketiga level soal, yaitu C4 (menganalisa), C5 (mengevaluasi) dan C6 (mengkreasi/mencipta) diperoleh data awal sebagai berikut: siswa yang berada pada tingkat kemampuan mengerjakan soal HOTS IPS pada kategori sangat rendah diperoleh sebanyak 3 siswa, siswa yang memperoleh kategori rendah ada 15 siswa, siswa yang memperoleh kategori cukup ada 7 siswa, siswa yang memperoleh kategori tinggi ada 1 siswa dan belum ada siswa yang memperoleh nilai dengan kategoru sangat tinggi. Rata-rata skor total dari ketiga level soal HOTS kelas VIIA berada pada kategori rendah, dengan rata-rata nilai 53,46. Jadi dapat disimpulkan bahwa siswa belum cukup mampu dalam mengerjakan soal HOTS IPS berdasarkan ketiga level soal HOTS tersebut.

Berdasarkan hasil test soal HOTS siswa yang rendah sebagaimana tergambar diatas, mendorong penulis untuk mencari akar permasalahannya, baik melalui pengamatan maupun hasil wawancara dengan guru IPS kelas VIIA SMPN 3 Sambit, antara lain diperoleh hal-hal sebagai berikut :(1). Proses pembelajaran yang berlangsung di sekolah belum optimal dan hanya berpusat pada guru (teacher oriented), (2). guru belum menggunakan model dan media pembelajaran, (3). guru belum menerapkan secara maksimal penggunaan indikator kemampuan berpikir tingkat tinggi, (4). siswa tidak diajak aktif dalam menemukan konsep, (5) soal yang dibuat pendidik dalam ujian sekolah sebagian besar hanya mencakup indikator kemampuan $\mathrm{C} 1, \mathrm{C} 2$ dan $\mathrm{C} 3$, belum mencakup dimensi menganalisis (C4), mengevaluasi (C5) dan mencipta (C6) 
Agar kondisi sebagaimana tergambar diatas tidak terjadi, maka idealnya dalam proses pembelajaran harus terjadi komunikasi dua arah antara guru dan peserta didik sehingga suasana pembelajaran lebih kondusif. Tidak ada lagi teacher center melainkan student center. Pembelajaran harus diajarkan oleh guru yang kompeten agar peserta didik memiliki sikap kritis dan kreatif. Menurut Zamroni dan Mahfudz (2009: 30) mengatakan bahwa ada empat cara meningkatkan keterampilan berpikir kritis, yaitu dengan: (1). Menerapkan model pembelajaran tertentu, (2). mengkritisi buku, (3). Menyuruh anak bercerita, (4). Memberikan pertanyaan dengan model-model tertentu. Sedangkan Suprijono (2016: 29) mengatakan bahwa penggunaan model pembelajaran dapat meningkatkan ketrampilan berpikir kritis. Namun demikian tidak semua model pembelajaran secara otomatis dapat meningkatkan ketrampilan berpikir kritis. Hanya model pembelajaran tertentu yang akan meningkatkan ketrampilan berpikir kritis.

Salah satu model pembelajaran yang dapat digunakan adalah model penemuan (discovery learning) yang akan membuat pembelajaran lebih bermakna karena akan mengubah kondisi belajar yang pasif menjadi aktif dan kreatif serta mengubah pembelajaran yang semula teacher oriented ke student oriented. Metode pembelajaran discovery learning merupakan suatu metode pengajaran yang menitikberatkan pada aktifitas dan keterlibatan peserta didik melalui penemuan. Hosnan (dalam Lestari, 2020: 7) mengatakan bahwa discovery learning merupakan suatu model pembelajaran untuk mengembangkan cara belajar aktif dengan menemukan sendiri, menyelidiki sendiri, sehingga hasil yang diperoleh akan setia dan tahan lama dalam ingatan, peserta didik juga dapat belajar berpikir analisis dan belajar memecahkan masalahnya sendiri.

Dalam proses belajar mengajar seorang guru dituntut lebih kreatif dalam melaksanakan proses kegiatan belajar mengajar, khususnya dalam penggunaan media pembelajaran sebagai perantara dalam menyampaikan materi pelajaran. Media pembelajaran merupakan komponen integral dari sistem pembelajaran. Artinya media pembelajaran tidak dapat dipisahkan dari proses pembelajaran. Kurangnya penggunaan media pada proses pembelajaran dapat menurunkan berfikir tingkat tinggi (HOTS), peserta didik akan cenderung merasa bosan dengan pembelajaran yang hanya menggunakan media seadanya. Dengan bantuan media yang menarik, peserta didik akan mudah untuk memahami materi pelajaran dan hal ini diduga akan berdampak positif terhadap hasil belajar peserta didik.

Salah satu media pembelajaran yang dapat menarik perhatian peserta didik dan menjadikan peserta didik lebih aktif dan keratif adalah media video. Video pembelajaran merupakan sebuah media yang cukup sering digunakan oleh guru. Dengan menggunakan video proses pembelajaran akan menjadi semakin menarik. Tetapi tidak semua jenis video bisa memacu peningkatan HOTS. Video yang dapat meningkatkan HOTS adalah yang berbasis masalah atau kasus, dikarenakan peserta didik akan terangsang untuk berfikir lebih tinggi tidak hanya sekedar menghafal.

Berdasarkan pada permasalahan diatas, peneliti menganggap bahwa model Discovery Learning berbantuan video dapat membekali siswa agar mempunyai ketrampilan kolaborasi dan ketrampilan berpikir tingkat tinggi. Rumusan masalah dalam penelitian ini adalah: 1). Bagaimana penerapan model Discovery Learning berbantuan media video dalam pembelajaran IPS guna meningkatkan Higher Other Thinking Skill siswa Kelas VIIA SMPN 3 Sambit, 2). Apakah penerapan model Discovery Learning berbantuan Media Video dalam pemebelajaran IPS dapat meningkatkan Higher Other Thinking Skill peserta didik kelas VIIA SMPN 3 Sambit. Adapun tujuan dari penelitian ini adalah: 1). Untuk mendiskripsikan dan menjelaskan penerapan Model Discovery Learning berbantuan media video dalam pembelajaran IPS di SMPN 3 Sambit, 2). Untuk mendiskripsikan dan menjelaskan penerapan Model Discovery Learning berbantuan media Video dapat atau tidak untuk meningkatkan HOTS peserta didik dalam pembelajaran IPS kelas VIIIA SMPN 3 Sambit.

\section{Discovery Learning}

Solusi untuk mencapai pembelajaran yang ideal dibutuhkan penerapan pembelajaran dengan menerapkan model discovery learning berbantuan video untuk meningkatkan ketrampilan tingkat tinggi dan ketrampilan kolaborasi. Discovery learning merupakan salah satu model pembelajaran yang berpusat pada peserta didik, artinya pembelajaran harus melibatkan kemampuan peserta didik secara maksimal untuk menggali dan mengidentifikasi 
sehingga mereka dapat menemukan pengetahuan dengan sendiri. Budiningsih (2005: 43) mengatakan bahwa cara belajar dengan memahami konsep, arti, dan hubungan melalui proses intuitif untuk akhirnya sampai kepada suatu kesimpulan dinamakan dengan Model pembelajaran Discovery Learning. Dalam mengaplikasikan discovery learning guru berperan sebagai pembimbing dengan memberikan kesempatan kepada siswa untuk belajar secara aktif. Video merupakan salah satu jenis media audio visual, yaitu media yang mengandalkan indera pendengaran dan indera penglihatan. Media ini dapat menambah minat siswa dalam belajar karena siswa dapat menyimak sekaligus melihat gambar.

Langkah-langkah model Discovery Learning berbantuan video dalah : 1) stimulasi (pemberian rangsangan), 2) problem statment (identifikasi masalah), 3) data collection (pengumpulan data), 4) data processing (pengumpulan data), 5) verification (pembuktian), 6) generalization (penarikan kesimpulan) (Syah, 2004: 244). Model discovery learning berbantuan video sangat efektif diterapkan dalam pembelajaran karena siswa akan termotivasi untuk belajar menemukan sendiri, siswa merasa puas yang akan mendorong dirinya untuk menemukan dan menemukan lagi sehingga semangat belajarnya meningkat.

\section{Keterampilan HOTS}

Abdul Sani (2019: 2) mengatakan bahwa ketrampilan berpikir tingkat tinggi (HOTS) meliputi kemampuan berpikir kritis, logis, reflekstif, metakognitif dan kreatif. Kemampuan berpikir kritis diperlukan untuk menyelesakan masalah dan membuat keputusan. HOTS akan berkembang apabila individu dihadapkan pada masalah yang baru, pertanyaan yang menantang serta menghadapi ketidakpastian. Kemampuan berpikir tingkat tinggi akan berkembang jika seseorang mempunyai informasi yang disimpan dalam ingatan, dan memperoleh informasi baru, kemudian menghubungkan dan mengembangkan informasi tersebut untuk tujuan atau jawaban terhadap situasi yang dihadapi. Higher Order Thinking Skills (HOTS), meliputi: 1) berpikir kritis, 2). Berpikir kreatif, 3). Problem solving, 4). Membuat keputusan.

\section{METODE}

Penelitian ini telah dilaksanakan pada bulan Maret sampai dengan Desember Tahun Pelajaran 2021/2022, bertempat di SMPN 3 Sambit Ponorogo. Populasi dari penelitian ini adalah seluruh peserta didik kelas VIIA yang berjumlah 26 orang, terdiri dari 15 laki-laki dan 11 perempuan.

Jenis penelitian ini adalah Penelitian Tindakan Kelas (PTK) terdiri dari 2 siklus. Prosedur umum penelitian ini melalui tahapan planning, acting, observing dan reflecting dengan menggunakan pendekatan kualitatif. Penelitian ini dilaksanakan dengan menggunakan model discovery learning berbantuan Video.

Adapun jenis data pada penelitian ini adalah kualitatif (hasil observasi proses diskusi dan presentasi) dan data kuantitatif (hasil pretes dan postes). Teknik yang digunakan dalam penelitian ini adalah, Pertama: adalah teknik tes yang digunakan adalah tes hasil belajar IPS. Pengertian tes adalah merupakan alat atau prosedur untuk mengetahui dan mengukur sesuatu dalam suasana tertentu berdasarkan aturan yang sudah ditentukan (Arikunto, 2010: 53). Test yang dimaksud adalah tes yang dilaksanakan setelah akhir pembelajaran untuk mengetahui sejauh mana kemampuan yang telah dicapai oleh siswa dalam mata pelajaran tertentu.

Pelaksanaan penelitian ini diawali dengan memberikan pretest soal HOTS pada semua peserta didik kelas VIIA di awal pertemuan untuk mengetahui kemampuan dasar serta HOTS peserta didik pada materi interaksi sosial dan Lembaga sosial. Kemudian dilakukan pembelajaran dengan model dicovery learning berbantuan video pada kelas tersebut. Selanjutnya pada akhir pertemuan, diberikan posttest soal HOTS untuk melihat pengaruh pembelajaran yang diberikan terhadap penguasaan HOTS peserta didik.

Langkah yang dilakukan dalam menyusun tes hasil belajar mata pelajaran IPS meliputi: a) menyusun kisi-kisi belajar, b) menyusun butir soal dan lembar jawaban, c) menyusun norma dan 
tabel penilaian, d) menyusun kunci jawaban. Keterampilan berpikir tingkat tinggi peserta didik dianalisis berdasarkan 3 indikator soal penilaian level taksonomi Bloom meliputi kemampuan menganalisis (C4), mengevaluasi (C5), dan mencipta (C6). Data keterampilan berpikir tingkat tinggi digunakan untuk mengetahui tingkat pemahaman peserta didik terkait materi yang diajarkan. HOTS peserta didik diperoleh dari nilai pretest dan posttest. Selanjutnya, skor pencapaian HOTS peserta didik yang diperoleh kemudian diklasifikasikan ke dalam kriteria pada table:

TABEL1. Skor dan Kategori

\begin{tabular}{|c|c|}
\hline Skor & Kategori \\
\hline$\ldots \ldots-39,99$ & Sangat Rendah \\
\hline $40,00-54,99$ & Rendah \\
\hline $55,00-69,99$ & Cukup \\
\hline $70,00-84,99$ & Tinggi \\
\hline $85,00-100$ & Sangat Tinggi \\
\hline
\end{tabular}

Sumber : Modifikasi (Riduwan, 2010)

Kedua adalah teknik pengamatan, yang digunakan dalam penelitian ini meliputi pengamatan tentang kemampuan peserta didik dalam proses diskusi dan presentasi. Langkah langkah yang dilakukan dalam menyusun instrumen kemampuan diskusi dan presentasi meliputi: a) menentukan kisi-kisi, b) menyusun aspek, c) menyusun indikator, d) menyusun lembar pengamatan. Kemampuan diskusi dan presentasi dianalisis berdasarkan 5 indikator yaitu: : (1) Kerja sama, (2) Keberanian menyampaikan pendapat, (3) Keranian berargumen/menjawab pertanyaan, (4) Kemampuan menyimpulkan, (5) Menghargai pendapat teman. Ketrampilan menyampaikan presentasi dianalisis berdasarkan 5 indikator: (1) Berani Presentasi didepan kelas, (2) Berani berpendapat, bertanya, atau menjawab pertanyaan, (3) Berpendapat atau melakukan kegiatan tanpa ragu-ragu, (4) Mampu membuat keputusan dengan cepat, (5) Menyimpulkan Materi. Indikator keterampilan proses diskusi dan presentasi dihitung dengan membagi jumlah skor yang diperoleh dengan skor maksimum kemudian dikalikan dengan 100. Persentase keterampilan proses diskusi dan presentasi yang diperoleh kemudian diinterpretasikan sesuai tabel berikut;

TABEL 2. Skor dan Kriteria Penilaian proses

\begin{tabular}{|c|c|}
\hline Skor & Kriteria \\
\hline $3,33<$ skor $\leq 4,00$ & Sangat Baik \\
\hline $2,33<$ skor $\leq 3,33$ & Baik \\
\hline $1,33<$ skor $\leq 2,33$ & Cukup \\
\hline skor $\leq 1,33$ & Kurang \\
\hline
\end{tabular}

(Sumber: Permendikbud No.81A Tahun 2013)

Pada penelitian ini peneliti menetapkan indikator kinerja sebagai berikut: 1), Keterlibatan siswa dalam proses pembelajaran IPS dikelas VIIA SMPN 3 Sambit dapat ditingkatkan menjadi 80\% dengan kategori BAIK, 2). Nilai HOTS peserta didik mencapai 30\% atau 8 siswa mendapatkan nilai dengan kategori tinggi. 3). Ketuntasan klasikal 75\% (siswa yang tuntas 75\%) dengan KKM 70.

\section{HASIL PENELITIAN}

Pembelajaran mata pelajaran IPS yang dilakukan peneliti pada umumnya banyak didominasi oleh guru. Siswa belum banyak terlibat dalam pembelajaran. Siswa belum banyak yang dapat bersikap kritis, belum banyak yang bersikap kreatif, belum banyak yang berani bertanya maupun menjawab pertanyaan. .Kondisi proses pembelajaran ini berakibat kemampuan High Order Thinking Skills rendah. Hal ini ditunjukan hasil pengamatan dari 26 siswa belum ada yang memiliki kemampuan High Order Thinking Skills tinggi. Partisipasi siswa dalam diskusi masih 51\%, kemampuan siswa dalam melaksanakan presentasi 54\%., belum ada siswa yang mendapatkan nilai HOTS dengan kategori sangat tinggi. Nilai terendah 36 dan nilai tertinggi 74, rata-rata skor total dari ketiga level soal HOTS adalah 52,85 berada pada kategori rendah. 
Adapun jumlah siswa yang mencapai KKM hanya ada 1 siswa sedangkan 25 siswa belum mencapai KKM (70)

\section{SIKLUS I}

Pada bagian perencanaan ini, kegiatan yang telah dilakukan pada penelitian tindakan kelas untuk meningkatkan HOTS siswa pada mata pelajaran IPS melalui penerapan model Discovery Learning berbantuan Video, dengan Langkah-langkah sebagai berikut; a). telah ditetapkan setting dan waktu pelaksanaan penelitian dengan 2 siklus dan tiap siklus 2 pertemuan sesuai dengan rancangan penelitian, b). telah ditetapkan materi pembelajaran, yaitu interaksi social, meliputi: pengertian, proses dan syarat-syarat inetraksi social. c). Telah dibuat izin penelitian, d). Telah dibuat rancangan penelitian terdiri dari instrumen proses, e). telah disusun rencana pelaksanaan pembelajaran lengkap dengan lembar kerja, f). telah disusun tes hasil belajar (kemampuan mengerjakan soal HOTS) yang terdiri dari kisi-kisi, butir soal, lembar jawab, kunci jawaban, dan pedoman penskoran.

Pengamatan yang dilakukan mencakup dua kegiatan utama yaitu (1) melakukan observasi siswa dalam melaksanakan tindakan, dan (2) menilai hasil tindakan. Adapun hasilnya sebagai berikut:

1. Pengamatan terhadap Siswa dalam mengikuti Diskusi

Melakukan pengamatan terhadap 26 siswa ketika mengikuti (sebagai peserta) diskusi kelompok. Instrument data berupa lembar pengamatan yang terdiri dari 5 indikator, yaitu: (1) Kerja sama, (2) Keberanian menyampaikan pendapat, (3) Keranian berargumen/menjawab pertanyaan, (4) Kemampuan menyimpulkan, (5) Menghargai pendapat teman, dengan hasil pengamatan sebagai berikut:

TABEL.3. Data Pengamatan Diskusi Siklus I

\begin{tabular}{|c|c|}
\hline Kriteria & Frekvensi \\
\hline Kurang & 2 \\
\hline Cukup & 13 \\
\hline Baik & 8 \\
\hline Sangat Baik & 3 \\
\hline
\end{tabular}

Dari data diatas, dapat dijelaskan bahwa partisipasi anak dalam mengikuti sudah ada peningkatan bila dibanding sebelum ada tindakan. Siswa yang mendapatkan nilai dengan kategori sangat baik menjadi 3 siswa

2. Pengamatan terhadap Presentasi Siswa

Mengadakan pengamatan terhadap pelaksanaan presentasi hasil diskusi. Instrument data berupa lembar pengamatan yang terdiri dari 5 indikator, yaitu: (1) Berani Presentasi didepan kelas, (2) Berani berpendapat, bertanya, atau menjawab pertanyaan, (3) Berpendapat atau melakukan kegiatan tanpa raguragu, (4) Mampu membuat keputusan dengan cepat, (5) Menyimpulkan Materi, diperoleh data sebagai berikut:

TABEL.3. Data Pengamatan Presentasi Siklus I

\begin{tabular}{|c|c|}
\hline Kriteria & Frekvensi (kelompok) \\
\hline Kurang & 0 \\
\hline Cukup & 2 \\
\hline Baik & 2 \\
\hline Sangat Baik & 1 \\
\hline
\end{tabular}

Berdasar data diatas, kemampuan siswa dalam melakukan presentasi hasil diskusi, ada 1 kelompok (5 siswa) yang mendapatkan nilai dengan kategori sangat baik, sedangkan tidak ada kelompok yang mendapatkan nilai dengan kategori kurang.

3. Kemampuan mengerjakan soal HOTS

Data tentang HOTS siswa diambil setelah melakukan pembelajaran pada akhir siklus I. Diberikan 5 soal, terdiri dari 60\%, 3 butir soal HOTS (soal no 1-3) dan 40\% 2 butir soal LOTS (soal no 4-5) diperoleh data sebagai berikut: 
TABEL.4. Data Penguasaan HOTS Siswa Siklus I

\begin{tabular}{|c|c|}
\hline Kriteria & Frekvensi (kelompok) \\
\hline Sangat Rendah & 1 \\
\hline Rendah & 7 \\
\hline Cukup & 10 \\
\hline Tinggi & 6 \\
\hline Sangat Tinggi & 2 \\
\hline
\end{tabular}

Berdasarkan data diatas dapat dijelaskan, bahwa siswa yang berada pada tingkat kemampuan mengerjakan soal HOTS IPS pada kategori sangat rendah sebanyak 1 siswa, siswa dalam kategori rendah ada 7 siswa, siswa dalam kategori cukup ada 10 siswa, siswa dalam kategori tinggi ada 6 siswa dan ada 2 siswa yang berada kategori sangat tinggi. Rata-rata skor total dari ketiga level soal HOTS adalah 62,31 berada pada kategori cukup. Adapun jumlah siswa yang mencapai KKM ada 8 siswa, masih ada 18 siswa belum mencapai KKM (70)

\section{Refleksi}

Hasil diskusi refleksi dengan kolaborator didapatkan sebagai berikut: 1). Jumlah anggota masing-masing kelompok diskusi masih cukup besar, sehingga partisipasi/peran masing-masing anggota kelompok masih kurang, 2). Waktu dalam berdiskusi kelompok perlu ditambah, agar semua siswa bisa berperan aktif secara maksimal, 3). Waktu yang disediakan untuk mengerjakan soal postest soal HOTS kurang, sehingga hasilnya juga kurang optimal. Masih 30\% dari 26 siswa yang mendapatkan nilai HOTS tinggi dan sangat tinggi, serta masih ada 18 siswa $(62,23 \%)$ yang belum mencapai nilai sesuai KKM, 4). Bimbingan guru perlu diintensifkan agar siswa yang berperan aktif dalam pembelajaran semakin bertambah.

\section{Siklus II}

Pada bagian perencanaan ini, kegiatan yang telah dilakukan pada penelitian tindakan kelas untuk meningkatkan HOTS siswa pada mata pelajaran IPS melalui penerapan model Discovery Learning berbantuan Video, dengan Langkah-langkah sebagai berikut; a). telah ditetapkan kembali materi pembelajaran, yaitu pengertian, jenis, fungsi Lembaga social serta pengaruh interaksi social terhadap pembentukan Lembaga social, b). Telah dibuat Kembali rancangan penelitian terdiri dari instrumen proses hasil tindakan, c). telah disusun Kembali Rencana Pelaksanaan Pembelajaran lengkap dengan lembar kerja, d). telah disusun tes hasil belajar (kemampuan mengerjakan soal HOTS) yang terdiri dari kisi-kisi, butir soal, lembar jawab, kunci jawaban, dan pedoman penskoran.

Pengamatan yang dilakukan mencakup dua kegiatan utama yaitu (1) melakukan observasi siswa dalam melaksanakan tindakan, dan (2) menilai hasil tindakan. Adapun hasilnya sebagai berikut:

1. Pengamatan terhadap Siswa dalam mengikuti Diskusi

Melakukan pengamatan terhadap 26 siswa ketika mengikuti (sebagai peserta) diskusi kelompok. Instrument data berupa lembar pengamatan yang terdiri dari 5 indikator, yaitu: (1) Kerja sama, (2) Keberanian menyampaikan pendapat, (3) Keranian berargumen/menjawab pertanyaan, (4) Kemampuan menyimpulkan, (5) Menghargai pendapat teman, dengan hasil pengamatan sebagai berikut:

TABEL.5. Data Pengamatan Diskusi Siklus II

\begin{tabular}{|c|c|}
\hline Kriteria & Frekvensi \\
\hline Kurang & 0 \\
\hline Cukup & 0 \\
\hline Baik & 14 \\
\hline Sangat Baik & 12 \\
\hline
\end{tabular}

Dari data diatas, dapat dijelaskan bahwa partisipasi anak dalam mengikuti sudah ada peningkatan bila disbanding sebelum ada tindakan dan setelah siklus I. Siswa yang mendapatkan nilai 
dengan kategori sangat baik menjadi 12 siswa, dan tidak ada lagi siswa yang berada dikategori kurang dan cukup

2. Pengamatan terhadap Presentasi Siswa

Mengadakan pengamatan terhadap pelaksanaan presentasi hasil diskusi. Instrument data berupa lembar pengamatan yang terdiri dari 5 indikator, yaitu: (1) Berani Presentasi didepan kelas, (2) Berani berpendapat, bertanya, atau menjawab pertanyaan, (3) Berpendapat atau melakukan kegiatan tanpa raguragu, (4) Mampu membuat keputusan dengan cepat, (5) Menyimpulkan Materi, diperoleh data sebagai berikut:

TABEL.6. Data Pengamatan Presentasi Siklus II

\begin{tabular}{|c|c|}
\hline Kriteria & Frekvensi (kelompok) \\
\hline Kurang & 0 \\
\hline Cukup & 1 \\
\hline Baik & 1 \\
\hline Sangat Baik & 3 \\
\hline
\end{tabular}

Berdasar data diatas, kemampuan siswa dalam melakukan presentasi hasil diskusi, tidak ada lagi kelompok yang mendapatkan nilai dengan kategori kurang, pada siklus II ini sudah ada 3 kelompok (16 siswa) yang mendapatkan nilai dengan kategori sangat baik,

3. Kemampuan mengerjakan soal HOTS

Data tentang HOTS siswa diambil setelah melakukan pembelajaran pada akhir siklus II. Diberikan 5 soal, terdiri dari 60\%, 3 butir soal HOTS (soal no 1-3) dan 40\% 2 butir soal LOTS (soal no 4-5) diperoleh data sebagai berikut:

TABEL.7. Data Penguasaan HOTS Siswa Siklus II

\begin{tabular}{|c|c|}
\hline Kriteria & Frekvensi (kelompok) \\
\hline Sangat Rendah & 0 \\
\hline Rendah & 3 \\
\hline Cukup & 3 \\
\hline Tinggi & 13 \\
\hline Sangat Tinggi & 7 \\
\hline
\end{tabular}

Berdasarkan data diatas dapat dijelaskan, bahwa tidak ada lagi siswa yang berada pada tingkat kemampuan mengerjakan soal HOTS IPS pada kategori sangat rendah, siswa dalam kategori rendah ada 3 siswa, siswa dalam kategori cukup ada 3 siswa, siswa dalam kategori tinggi ada 13 siswa dan sudah ada 7 siswa yang berada kategori sangat tinggi. Rata-rata skor total dari ketiga level soal HOTS adalah 79,46 berada pada kategori tinggi. Adapun jumlah siswa yang mencapai KKM/tuntas ada 21 siswa, tinggal 5 siswa belum tuntas/belum mencapai KKM (70)

\section{Reflesi}

Hasil diskusi refleksi siklus II dengan kolaborator didapatkan sebagai berikut: 1). partisipasi/peran masing-masing anggota kelompok sudah efektif, siswa yang terlibat aktif dalam pembelajaran semakin bertambah, 2). Waktu untuk berdiskusi kelompok sudah cukup, sehingga semua siswa bisa berperan aktif secara maksimal, 3). Dari 26 siswa yang mendapatkan nilai HOTS tinggi ada 13 siswa dan nilai HOTS sangat tinggi sudah ada 7 siswa, 4). Tingkat ketuntasan klasikal sebesar 80,76\%, sudah sesuai harapan atau di atas indikator keberhasilan yang ditetapkan $\geq 70 \%$. Oleh karena itu tidak dilaksanakan siklus lanjutan.

\section{PEMBAHASAN}

Penelitian tindakan kelas ini difokuskan pada upaya untuk meningkatkan HOTS siswa kelas VIIA SMPN 3 Sambit dengan menerapkan pendekatan pembelajaran model Discovery Learning berbantuan 
Video. Pembelajaran ini menuntut siswa untuk berperan akatif dalam melakukan percobaan dan melatih siswa untuk bisa bekerjasama dalam kelompok serta mengembangkan rasa percaya diri pada siswa. Tugas guru dalam pembelajaran ini sebagai fasilitator dan motivator bagi siswa. Dominasi guru dalam pembelajaran menggunakan model Discovery Learning berbantuan Video ini menjadi berkurang sehingga siswa terlibat aktif dalam pembelajaran.

Guru selalu mengoptimalkan interaksi. Pada akhir pembelajaran guru memberikan evaluasi untuk mengetahui tingkat pemahaman pada siswa terhadap materi yang diajarkan. Sani (2019: 234) menyatakan bahwa, pembelajaran discovery merupakan metode pembelajaran cognitive yang menuntut guru lebih kreatif menciptakan situasi yang dapat membuat siswa belajar aktif menemukan pengetahuan sendiri.

Hasil penelitian ini menunjukkan bahwa pembelajaran Discovery Learning berbantuan Video terbukti mempengaruhi dan meningkatkan HOTS siswa, karena aktivitas pembelajaran yang semula berpusat pada guru, menjadi lebih berpusat kepada siswa, setelah menggunakan model Discovery Learning berbantuan Video yang terjadi komunikasi multiarah antara siswa dengan guru. Selain terbukti dapat meningkatkan HOTS siswa, model Discovery Learning berbantuan Video juga dapat membantu siswa untuk terbiasa aktif, meningkatkan pemahaman siswa dan memotivasi siswa dalam proses pembelajaran, meningkatkan percaya diri, sehingga siswa lebih berani berargumentasi, meningkatkan kemampuan siswa dalam membuat kesimpulanyang pada akhirnya dapat meningkatkan proses dan hasil pembelajaran.

Dari hasil pelaksanaan tindakan penelitian sebagaimana disampaikan di atas menunjukkan bahwa penggunakan Model Discovery Learning berbantuan Video dapat meningkatkan HOTS siswa. Hal itu tampak pada raihan komponen-komponen nilai dalam tabel di bawah ini:

TABEL 8. Rekapitulasi Pengamatan Diskusi

\begin{tabular}{|l|c|c|c|l|}
\hline \multicolumn{1}{|c|}{ Kategori } & PraSiklus & Siklus I & Siklus II & \multicolumn{1}{c|}{ Keterangan } \\
\hline Kurang & 9 & 2 & 0 & Mengalami penurunan \\
\hline Cukup & 11 & 13 & 0 & Mengalami penurunan \\
\hline Baik & 5 & 8 & 14 & Mengalami kenaikan \\
\hline Sangat Baik & 1 & 3 & 12 & Mengalami kenaikan \\
\hline
\end{tabular}

Hasil penelitian sebagaimana tersebut diatas, menunjukkan bahwa partisipasi siswa dalam pelaksanaan diskusi semakin meningkat, siswa yang mendapatkan nilai dengan kategori kurang dan cukup berangsur-angsur menurun, pada siklus II tidak ada siswa yang mendapatkan nilai dengan kategori kurang dan cukup. Siswa mulai berani mengemukakan pendapat, lebih berani menyampaikan argumentasi dalam menjawab pertanyaan, mempunyai kemampuan dalam membuat kesimpulan. Hasil pengamatan diskusi dapat digambarkan pada diagram berikut: 


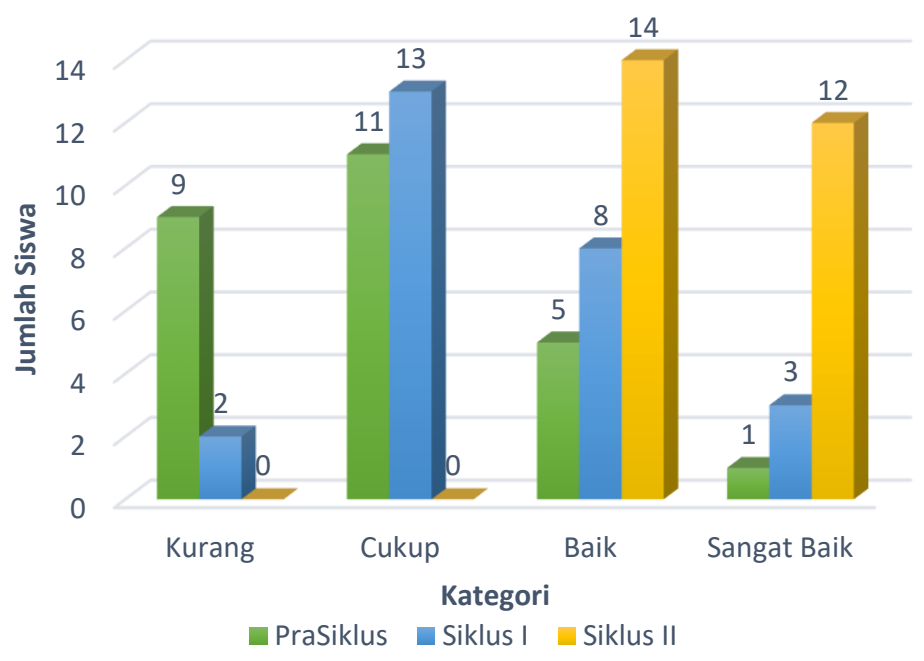

GAMBAR 1. Rekapitulasi Pengamatan Diskusi

Model Discovery Learning berbantuan Video terbukti bisa meningkatkan kemampuan presentasi siswa. Semua kelompok sudah mulai berani presentasi didepan kelas, berani berpendapat, bertanya, atau menjawab pertanyaan, mampu membuat keputusan dengan cepat, dan mampu menyimpulkan materi, sebagaimana terlihat pada table berikut:

TABEL 9. Rekapitulasi Presentasi Diskusi

\begin{tabular}{|c|c|c|c|l|}
\hline Kategori & PraSiklus & Siklus I & Siklus II & \multicolumn{1}{|c|}{ Keterangan } \\
\hline Kurang & 1 & 0 & 0 & Mengalami penurunan \\
\hline Cukup & 3 & 2 & 1 & Mengalami penurunan \\
\hline Baik & 1 & 2 & 1 & Mengalami penurunan \\
\hline Sangat Baik & 0 & 2 & 3 & Mengalami kenaikan \\
\hline
\end{tabular}

Setelah diadakan tindakan sampai dengan siklus II, diperoleh data sebagai berikut: tidak ada kelompok yang mendapatkan nilai dengan kategori kurang, ada 1 kelompok yang mendapatkan nilai dengan kategori cukup dan baik, sedangkan kelompok yang mendapatkan nilai sangat baik ada 3 kelompok, sebagaimana terlihat pada grafik dibawah ini.

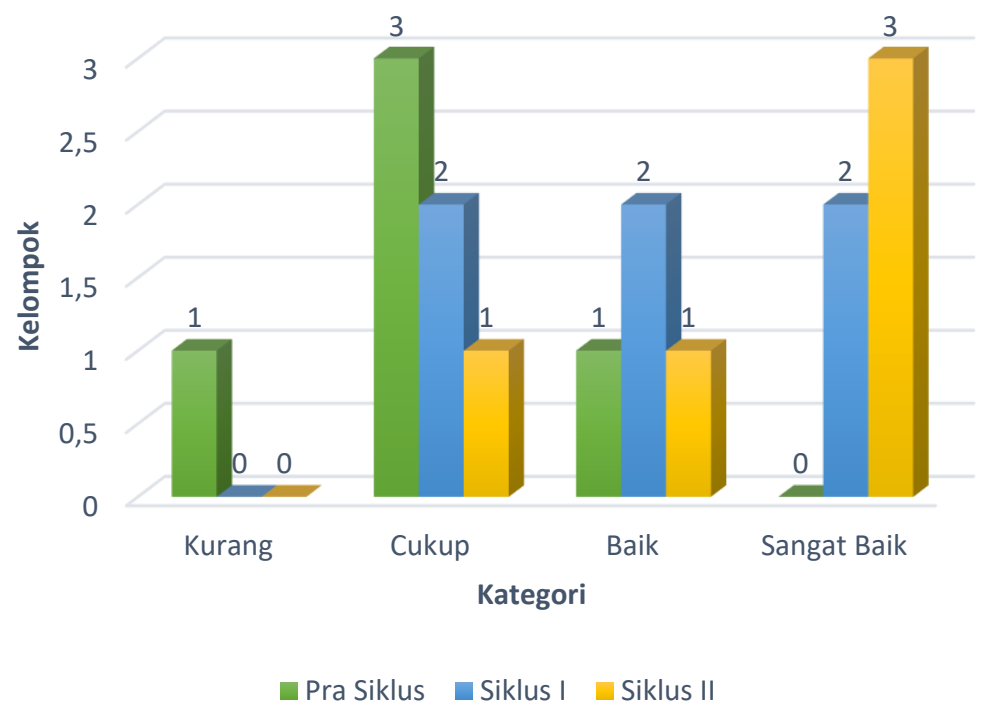

GAMBAR 2. Grafik Rekapitulasi Pengamatan Presentasi 
Dengan menerapkan model Discovery Learning berbantuan Video terbukti dapat meningkatlan HOTS siswa dalam pembejaran IPS kelas VIIA pada materi Inetraksi Sosial dan Lembaga Sosial. Peningkatan HOTS siswa dari prasiklus, siklus I dan siklus II sebagaimana terlihat pada tabel berikut:

Tabel 10. Rekapitulasi Nilai HOTS Siswa

\begin{tabular}{|c|c|c|c|l|}
\hline Kategori & PraSiklus & Siklus I & $\begin{array}{c}\text { Siklus } \\
\text { II }\end{array}$ & \multicolumn{1}{|l|}{ Ket. } \\
\hline Sangat Rendah & 3 & 1 & 0 & Mengalami penurunan \\
\hline Rendah & 15 & 7 & 3 & Mengalami Penurunan \\
\hline Cukup & 7 & 10 & 3 & Mengalami penurunan \\
\hline Tinggi & 1 & 6 & 13 & Mengalami kenaikan \\
\hline Sangat Tinggi & 0 & 2 & 7 & Mengalami Kenaikan \\
\hline
\end{tabular}

Setelah diadakan tindakan sampai pada siklus II, siswa yang mendapatkan nilai dengan kategori sangat rendah, rendah dan cukup mengalami penurunan, sedangkan siswa dengan kategori tinggi dan sangat tinggi mengalami kenaikan, tidak siswa yang mendapat nilai dengan kategori sangat tinggi sebelum ada tindakan, setelah pelaksanaan siklus I ada 13 (50\%) siswa yang mendapatkan nilai kategori sangat tinggi, sedangkan setelah siklus II sudah ada 7 siswa yang mendapatkan nilai dengan kategori sangat tinggi, sebagaimana terlihat pada grafik dibawah.

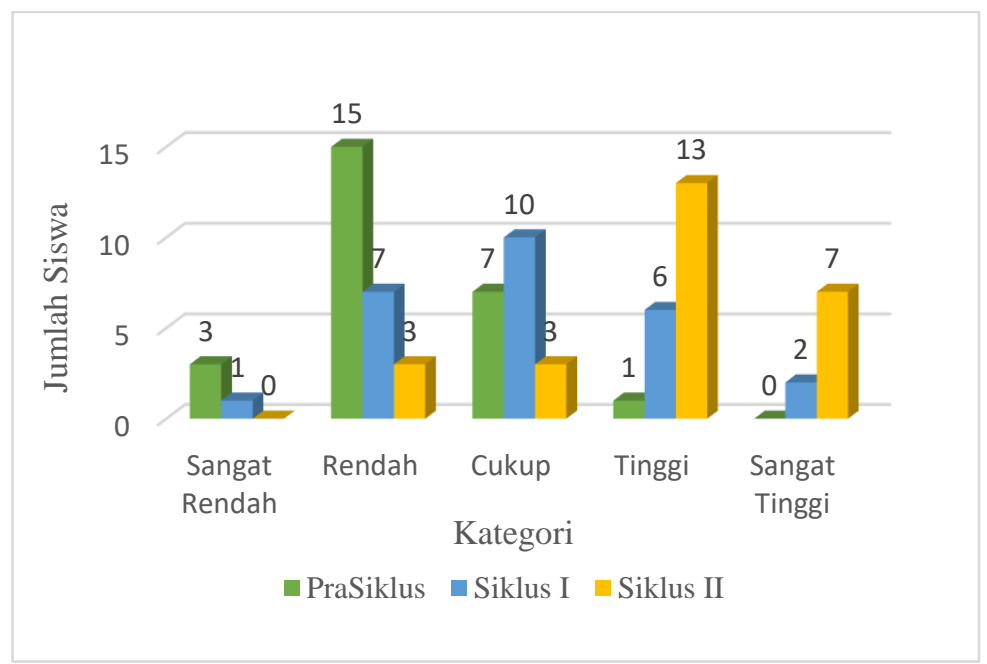

GAMBAR 3. Grafik Rekapitulasi Nilai HOTS Siswa

Sedangkan jumlah siswa yang mencapai nilai di atas dan/atau sama dengan Kriteria Ketuntasan Minimal (KKM) sebelum pemberian tindakan sampai dengan pemberian tindakan (siklus I dan siklus II) mengalami kenaikan dan sebaliknya, siswa yang tidak mencapai KKM mengalami penurunan. Hal tersebut dapat dilihat pada tabel di bawah ini

Tabel 11. Rekapitulasi Nilai Siswa Berdasarkan KKM

\begin{tabular}{|c|c|c|c|c|c|c|c|}
\hline \multirow{2}{*}{$\begin{array}{l}\text { Kriterian } \\
\text { Capaian } \\
\text { KKM }\end{array}$} & \multirow[b]{2}{*}{ KKM } & \multicolumn{2}{|c|}{ Prasiklus } & \multicolumn{2}{|c|}{ Siklus I } & \multicolumn{2}{|c|}{ Siklus II } \\
\hline & & $\begin{array}{c}\text { Jumlah } \\
\text { Siswa }\end{array}$ & $\%$ & $\begin{array}{c}\text { Jumlah } \\
\text { Siswa }\end{array}$ & $\%$ & $\begin{array}{c}\text { Jumlah } \\
\text { Siswa }\end{array}$ & $\%$ \\
\hline Tuntas & 70 & 1 & 3,90 & 8 & 30,76 & 21 & 80,76 \\
\hline Tidak Tuntas & 70 & 25 & 96,10 & 18 & 69,23 & 5 & 19,23 \\
\hline Jumlal & & 26 & 100 & 26 & 100 & 26 & 100 \\
\hline
\end{tabular}

Siswa yang mencapai KKM selalu mengalami kenaikan, dari prasiklus hanya ada 1 siswa (3,90\%), siklus I menjadi 8 siswa (30,76\%), sedangkan siklus II menjadi 21 siswa (80,76\%).Disajikan 
dalam bentuk diagram sebagai berikut:

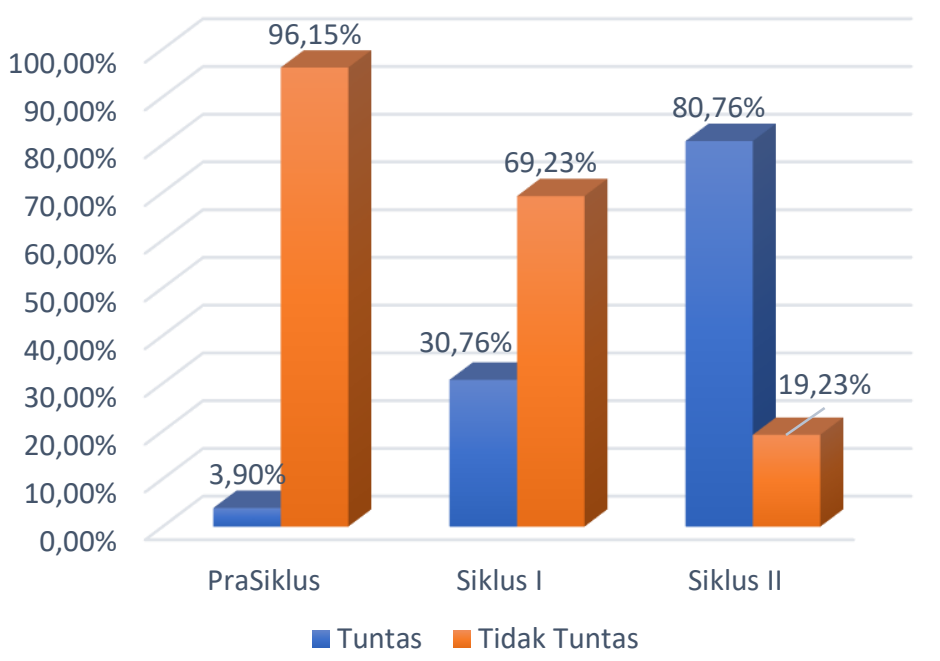

GAMBAR 5. Diagram Prosentase Ketuntasan

Dengan demikian hipotesis Tindakan yang menyatakan, bahwa Penerapan Model Discovery Learning Berbantuan Video dapat meningkatkan HOTS siswa SMPN 3 Sambit terbukti dan dapat diakatan berhasil. Artinya pembelajaran dengan menggunakan model Discovery Learning berbantuan Video memberikan pengaruh yang sangat besar terhadap HOTS siswa, sehingga siswa bisa memecahkan masalah dalam kegiatan pembelajaran maupun diluar pembelajaran.

\section{SIMPULAN}

Hasil Penelitian Tindakan Kelas (PTK) yang dilaksanakan dalam 2 siklus dengan menerapkan model Discovery Learning berbantuan Media Video, materi Interaksi Sosial dan Lembaga Sosial pada kelas VIIA SMPN 3 Sambit berhasil meningkatkan HOTS siswa. Hal ini diketahui berdasarkan hasil penelitian sebagai berikut:

1. Partisipasi siswa dalam mengikuti diskusi pada saat pembelajaran berlangsung, yang pada awalnya $51 \%$ mengalami peningkatan disiklus I menjadi $63 \%$ dan siklus II menjadi $81 \%$.

2. Kemampuan siswa dalam melaksanakan presentasi hasil diskusi kelompok juga mengalami peningkatan. Pada kondisi awal sebelum ada tindakan, masih 54\% setelah pelaksanaan siklus I menjadi $71 \%$ dan pada siklus II mencapai $81 \%$ dengan kategori baik.

3. Nilai HOTS siswa mengalami kenaikan 9,46\% pada siklus I menjadi 62,31 dan mengalami kenaikan 26\% pada siklus II, dengan kategori tinggi.

4. Prosentase ketuntasan klasikal mengalami kenaikan, sebelum ada tindakan hanya 3,90\% (hanya ada 1 siswa yang tuntas), disiklus I menjadi 30,76\% dan setelah pelaksanaan siklus II mengalami peningkatan yang signifikan, yaitu menjadi $80,76 \%$, hanya ada 5 siswa saja yang belum tuntas.

Berdasarkan pada kesimpulan diatas, maka masalah yang dihadapi oleh kelas VIIA dapat diselesaikan dengan menggunakan model Discovery Learning berbantuan Video pada materi Interaksi Sosial dan Lembaga Sosial. Tujuan dari penelitian ini juga telah tercapai, yaitu adanya peningkatan HOTS siswa sesuai dengan indikator yang telah ditentukan. Adapun manfaat dari penelitian ini telah nampak tercapainya semua indikator ketercapaian yang sudah ditetapkan.

\section{SARAN}

Dalam melaksanakan penelitian ini, peneliti menyadari ada beberapa keterbatasan saat mengadakan penelitian, antara lain: adanya kesulitan dalam melakukan observasi, karena dalam waktu yang bersamaan peneliti harus melakukan pengamatan kepada semua siswa, dan masalah dalam hal penyiapan lembar/instrument observasi. Berdasarkan hal tersebut, maka peneliti memberikan beberapa 
saran kepada calon peneliti, antara lain: 1).Instrument perlu dipersiapkan dengan baik agar penelitian berjalan dengan lancar, 2). Koordinasi yang baik dengan guru kelas sebagai kolaborator perlu diupayakan, 3). Penguasaan kelas dan manajemen waktu perlu dikuasai dengan baik sehingga proses pembelajaran dapat berlangsung dengan lancar sesuai dengan yang direncanakan, 4). Kemampuan berkomunikasi yang disesuaikan dengan tingkat pemahaman siswa penting untuk diusahakan.

\section{DAFTAR PUSTAKA}

Abdul Sani R. (2019). Pembelajaran Berbasis HOTS. Tangerang: Tira Smart

Arikunto, dkk. 2010. Penelitian Tindakan Kelas. Jakarta. Bumi Aksara

Budiningsih. (2005). Model Discovery Learning. Jakarta: Pustaka Mandiri, diakses tanggal 9 Januari 2021

http://edutaka.blogspot.com/2015/03/model-pembelajaran-discovery-learning.html pada jam 19.41

Lestari E. (2020). Model Pembelajaran Discovery Learning di SD. Sleman: Deepublish

Permendikbud No.81A Tahun 2013)

Riduan, \& Sunarto (2010). Pengantar Statistika Untuk Penelitian Pendidikan, Sosial, Ekonomi, Komunikasi, dan Bisnis (cetakan ketiga) Bandung: CV. Alfabeta.

Suprijono A. (2016). Model-Model Pembelajaran Emansipatoris, Yogjakarta: Pustaka Pelajar.

Syah. 2004. Psikologi Pendidikan dengan Pendekatan Baru. Bandung: PT Remaja Rosdakarya diakses tanggal 9 Januari 2021

http://edutaka.blogspot.com/2015/03/model-pembelajaran-discovery-learning.html pada jam 19.41

Zamroni \& Mahfudz. (2009), Panduan Tehnis Pembelajaran yang Mengembangkan Critical Thingking, Jakarta: Depdiknas

Basuki, Sudarmiani, Rifai. 2020. Improving Social Skill And Civics Learning Outcome Through Problem-Based Learning (Pbl) Assissted With Digital Literacy To The Xi Graders Of Titl Vocational High School Smk Gamaliel 1 Madiun. Diakses tanggal 14 Januari 2021 jam 13.51 file:///C:/Users/USER/Downloads/7565-20863-1-PB.pdf

Sudarmiani, Supri Wahyudi Utomo. 2018. Implementasi Pembelajaran Problem Solving Berbasis HOTS Pada Mata Pelajaran Ekonomi, Jurnal Ekonomi Pendidikan dan Kewirausahaan, Vol. 6. No. 1, Tahun 2018. Diakses tanggal 14 Januari 2021 Jam 14.05. https://journal.unesa.ac.id/index.php/jepk/article/view/5850/3523 